University of Nebraska - Lincoln

DigitalCommons@University of Nebraska - Lincoln

Faculty Publications in Computer \& Electronics Electrical \& Computer Engineering, Department Engineering (to 2015)

2011

\title{
Message from the Chair of Technical Program Committee
}

Tadeusz Wysocki

University of Nebraska-Lincoln, wysocki@uow.edu.au

Follow this and additional works at: https://digitalcommons.unl.edu/computerelectronicfacpub

Part of the Computer Engineering Commons

Wysocki, Tadeusz, "Message from the Chair of Technical Program Committee" (2011). Faculty Publications in Computer \& Electronics Engineering (to 2015). 105.

https://digitalcommons.unl.edu/computerelectronicfacpub/105

This Article is brought to you for free and open access by the Electrical \& Computer Engineering, Department of at DigitalCommons@University of Nebraska - Lincoln. It has been accepted for inclusion in Faculty Publications in Computer \& Electronics Engineering (to 2015) by an authorized administrator of DigitalCommons@University of Nebraska - Lincoln. 


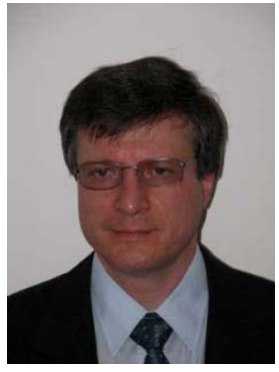

\section{Message from the Chair of Technical Program Committee}

On behalf of all the members of the Organizing Committee, I would like to welcome you to the $5^{\text {th }}$ International Conference on Signal Processing and Telecommunication Systems, ICSPCS'2011. The ICSPCS conferences evolved from the series of successful symposia and workshops, i.e. International Symposia on DSP and Communication Systems (DSPCS), and Workshops on the Internet, Telecommunications and Signal Processing (WITSP). As in the past, the Organizing Committee has succeeded this year in achieving an official technical co-sponsorship of the IEEE Communications Society for conference. As a result the ICSPCS'2011 conference has been listed in the IEEE database of the conferences and the proceedings will be published in IEEE Xplore.

This year response to the call for papers was very good, with 223 full paper submissions. All submitted papers have been put through a rigorous peer review process, and each paper received at least two but often three or more peer reviews. Based on those reviews, 83 papers have been accepted, and finally 81 included in the program - 48 for oral and 33 for poster presentations. To complement the program, the Organizing Committee invited a keynote speaker, Dr. Thaddeus Owens Walker III of United States Naval Academy. His address: Securing Wireless in the Cyberdomain will be a great addition to the already excellent program.

At this point, I wish to thank the authors who put so many efforts, first in preparing their manuscripts for submission, and then for incorporating reviewers' comments in the camera-ready papers. I extend my sincere thanks to the 68 members of the Technical Program Committee for organizing reviews for the submitted papers, and 222 reviewers for thorough reviews of the manuscripts.

I hope that you will take pleasure in staying in Waikiki Beach whose friendly atmosphere will facilitate peer-to-peer interactions and networking and be a pleasant supplement to the research benefits of the Conference.

Welcome to Honolulu and enjoy the Conference!

Tadeusz A Wysocki

TPC Chair, ICSPCS'2011 